Original article

\title{
Perbandingan produksi dan kualitas susu kambing Peranakan Ettawa pada dua peternakan yang berbeda di Kota Batu berdasarkan komposisi pakan
}

\section{Comparison of production and quality of Ettawa crossbreed goat milk from two different husbandry in Batu based on feed composition}

\author{
Chintyadhevi Aulia Rahmi ${ }^{1}$, Nenny Harijani ${ }^{2}$, Suwarno Suwarno ${ }^{3}$, Mohammad Anam Al

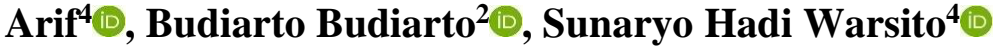 \\ ${ }^{1}$ Faculty of Veterinary Medicine, ${ }^{2}$ Division of Veterinary Public Health, \\ ${ }^{3}$ Division of Veterinary Microbiology, ${ }^{4}$ Division of Animal Husbandry \\ Faculty of Veterinary Medicine, Universitas Airlangga \\ *Corresponding author, e-mail: suwarno@fkh.unair.ac.id
}

Open access under CC BY - SA license, DOI: 10.20473/ovz.v10i3.2021.90-97

Received July 27 2021, Revised August 28 2021, Accepted November 212021

Published online December 12021

\begin{abstract}
This research aims to compare the production and quality of Ettawa crossbreed goat milk from two different husbandries in Batu based on the composition of the feed. This research used Ettawa crossbreed goat milk samples from the 3rd week period of the second lactation at Madukara and Green farms with three replicates collected within 3 days in a row. Proximate analysis showed that feed P1 composed of $51.53 \%$ dry matter; $2.74 \%$ ash; $10.94 \%$ crude protein; $4.93 \%$ crude fat; $16.34 \%$ crude fiber; $16.58 \%$ nitrogen-free extract (NFE) and $41.85 \%$ total digestible nutrients (TDN) with a total weight of feed consumed $5.1 \mathrm{~kg} /$ day per lactating doe; whereas P2 feed composed of $63.94 \%$ dry matter; $6.32 \%$ ash; $11.38 \%$ crude protein; $4.62 \%$ crude fat; $16.31 \%$ crude fiber; $25.31 \%$ NFE and $49.23 \%$ TDN with a total weight of feed consumed $5.46 \mathrm{~kg} /$ day per lactating doe. The data obtained are presented descriptively in tables. The results of this research showed that the total consumption of $\mathrm{P} 1$ ration resulted in a higher milk production $((892.22 \pm 99.92 \mathrm{vs} 661.11 \pm 19.39) \mathrm{mL} /$ day per doe $)$. In addition, in does fed P1 ration, milk fat content was higher $((5.68 \pm 0.21$ vs $3.42 \pm 0.24) \%)$ and dry matter was also higher $((14.4 \pm 0.36$ vs $12.14 \pm 0.25) \%)$.
\end{abstract}

Keywords: Ettawa crossbreed goat milk, feed composition, production, quality

\section{PENDAHULUAN}

Salah satu bangsa kambing perah yang sudah lama dikembangkan di Indonesia adalah kambing peranakan Ettawa, yang merupakan hasil persilangan kambing Ettawa dengan kambing kacang (Pribadiningtyas et al., 2012). Kambing peranakan Ettawa memiliki kemampuan menghasilkan susu yang lebih baik dibandingkan dengan kambing lokal. Produksi susu antara 1,5-3 liter per hari
(Mauladi et al., 2018).

Produksi susu adalah salah satu bagian penting dan tidak terpisahkan dari sistem reproduksi induk ternak perah. Produksi susu dapat ditingkatkan produktivitasnya melalui penerapan teknologi reproduksi. Penerapan teknologi reproduksi diupayakan melalui manipulasi secara hormonal dari poros hipotalamus-hipofisis-ovarium pada siklus reproduksi. Satu siklus reproduksi dari seekor kambing betina terdiri dari estrus, mating, 
gravid, kidding dan diakhiri dengan laktasi untuk memproduksi air susu (Luo et al., 2019).

Secara fisiologi, proses perkembangan kelenjar susu diawali dari tahap fetus hingga dewasa kelamin tercapai. Selanjutnya selama siklus birahi perkembangan kelenjar susu terus berlangsung dan perkembangan lebih lanjut terjadi selama masa kebuntingan dan permulaan laktasi. Pada awal kebuntingan, terjadi perubahan yang signifikan dari sistem endokrinologi, dimana terjadi pertumbuhan kelenjar susu yang dipengaruhi oleh beberapa hormon seperti hormon pertumbuhan, prolaktin, estrogen dan progesteron. Pada awal masa laktasi terjadi peningkatan aliran darah pada kelenjar susu, sehingga terjadi peningkatan kadar hormon dalam upaya pengaturan sintesa air susu Pengaturan sintesis air susu oleh hormon ini ditujukan untuk peningkatan distribusi nutrisi ke kelenjar susu (Svennersten-Sjaunja dan Olsson, 2005).

Upaya dalam peningkatan produksi susu kambing perah dipengaruhi oleh faktor-faktor yang berpengaruh pada kemampuan produksi susu ternak perah (Sanz et al., 2009). Pakan yang baik dan cukup akan meningkatkan kualitas kambing, susu dan anakan yang dihasilkan (Wasiati dan Edi, 2018). Pakan yang berkualitas dipengaruhi oleh susunan komposisi pakan yang diberikan kepada ternak. Pakan yang berkualitas memberikan nutrisi darah yang lebih tinggi dan berkolerasi terhadap proses sintesis susu di dalam sel sekretoris kelenjar ambing yang akhirnya meningkatkan produksi dan kualitas air susu yang dihasilkan (Adriani et al., 2014). Penelitian ini bertujuan membandingkan produksi dan kualitas susu peranakan Ettawa berdasarkan komposisi pakan yang berbeda.

\section{MATERI DAN METODE}

\section{Lokasi Penelitian}

Secara astronomis Kota Batu terletak di $112^{\circ} 17^{\prime} 10,90^{\prime \prime}-122^{\circ} 57^{\prime} 11^{\prime \prime}$ Bujur Timur dan $7^{\circ} 44^{\prime} 55,11^{\prime \prime}-8^{\circ} 26^{\prime} 35,45$ Lintang Selatan. Kota Batu terletak 800 meter diatas permukaan air laut, dengan kondisi topografi pegunungan dan perbukitan dengan temperatur rata-rata $21,5^{\circ} \mathrm{C}$ $\left(14,9-27,2^{\circ} \mathrm{C}\right)$ rata-rata kelembaban nisbi udara $86 \%$ dan kecepatan angin 10,73 km/jam, curah hujan sekitar $2471 \mathrm{~mm}$ dan hari hujan 134 hari/tahun (Profil Kota Batu, 2021).

\section{Hewan coba}

Penelitian ini menggunakan enam ekor kambing dengan jenis sama (Peranakan Ettawa), periode laktasi kedua dengan masa laktasi pada minggu ketiga. Penelitian ini dilaksanakan di dua peternakan yang berbeda di Kota Batu, yaitu Madukara (perlakuan pakan P1) dan Green farm (perlakuan pakan P2).

\section{Pakan ternak}

Sampel pakan yang didapat dari masingmasing peternakan dianalisis proksimat lengkap untuk mendapatkan komposisi pakan, yang dilakukan di eks Laboratorium Makanan Ternak Divisi Peternakan Fakultas Kedokeran Hewan Universitas Airlangga. Berdasarkan data komposisi ransum dan hasil analisis proksimat dihitung total konsumsi nutrien pakan dari bahan pakan Kambing Peranakan Ettawa masing-masing kelompok.

\section{Sampel dan pemeriksaan kualitas susu}

Masing-masing kambing perah Peranakan Ettawa diukur volume produksi susu dan diambil sampel pada setiap pemerahan pagi sebanyak per tiga hari berturut-turu sebagai ulangan.

Sampel susu diambil sebanyak $220 \mathrm{~mL}$ untuk diukur suhu dan berat jenis dengan laktodensimeter, pemeriksaan selanjutnya dilakukan di laboratorium Balai Besar Pelatihan Peternakan Kota Batu. Sampel susu sebanyak $3 \mathrm{~mL}$ diambil untuk pemeriksaan derajat asam dengan alkohol $70 \%$. Pemeriksaan dilakukan secara organoleptis untuk mengamati warna, bau, rasa dan kekentalan. Susu disaring dengan kertas saring untuk menilai kebersihan susu. Sampel susu sebanyak $20 \mathrm{~mL}$ dituang ke dalam beaker glass untuk dilakukan uji kualitas (kadar lemak, protein dan laktosa) susu menggunakan lactoscan. Bahan kering susu dihitung dengan rumus Fleischmann. Kandungan bahan kering tanpa lemak dalam susu dihitung dengan mengurangi bahan kering susu dengan kandungan lemak susu. 


\section{Analisis Data}

Data yang diperoleh disajikan secara deskriptif dan diuji statistik menggunakan uji $\mathrm{t}$ pada taraf kepercayaan $95 \%$ menggunakan Statistical Product and Service Solutions (SPSS) versi 20.

\section{HASIL}

Berdasarkan formula bahan ransum (Tabel 1), dan hasil analisis proksimat (Tabel 2), maka didapat total konsumsi nutrien pakan masing-masing kelompok (Tabel 3). Volume produksi (mL/hari) dan berat jenis, serta kualitas susu kambing Peranakan Ettawa berdasarkan komposisi pakan disajikan pada Tabel 4 dan Tabel 5. Volume produksi, kadar lemak dan kadar bahan kering susu yang berasal dari kambing Peranakan Ettawa Kelompok P1 lebih tinggi $(\mathrm{p}<0,05)$ dibandingkan pada Kelompok P2. Variabel-variabel yang lain (berat jenis, kadar protein, laktosa, dan bahan kering tanpa lemak) tidak berbeda nyata ( $p>0,05)$.

Tabel 1 Formula bahan ransum induk laktasi kambing Peranakan Ettawa

\begin{tabular}{lclc}
\hline \multicolumn{1}{c}{$\begin{array}{c}\text { bahan pakan } \\
\text { P1 }\end{array}$} & $\begin{array}{c}\text { berat } \\
\text { (kg/ekor/hari) }\end{array}$ & \multicolumn{1}{c}{$\begin{array}{c}\text { bahan pakan } \\
\text { P2 }\end{array}$} & $\begin{array}{c}\text { berat } \\
\text { (kg/ekor/hari) }\end{array}$ \\
\hline rumput gajah (Odot) & 1,00 & daun Kaliandra & 1,39 \\
kulit jagung & 1,85 & daun Pahitan & 1,91 \\
silase & 0,42 & rumput gajah & 1,16 \\
pollard & 0,56 & kangkung kering & 0,21 \\
kulit kedelai & 1,06 & pollard & 0.56 \\
susu A & 0,21 & kulit kedelai & 0,23 \\
\hline \multicolumn{1}{c}{ jumlah } & 5,10 & \multicolumn{1}{c}{ jumlah } & 5,46 \\
\hline
\end{tabular}

Tabel 2 Hasil analisis proksimat (\%) ransum induk laktasi kambing Peranakan Ettawa

\begin{tabular}{lrr}
\hline komposisi & \multicolumn{1}{c}{ P1 } & \multicolumn{1}{c}{ P2 } \\
\hline bahan kering & 51,53 & 63,94 \\
abu & 2,74 & 6,32 \\
protein kasar & 10,94 & 11,38 \\
lemak kasar & 4,93 & 4,62 \\
serat kasar & 16,34 & 16,31 \\
BETN & 16,58 & 25,31 \\
TDN & 41,845 & 49,23
\end{tabular}

BETN: Bahan Ekstrak Tanpa Nitrogen; TDN: Total Digestible Nutrient; P1: ransum peternakan 1; P2: ransum peternakan 2.

\section{DISKUSI}

Pertumbuhan ambing merupakan bagian integral dari proses reproduksi, karena pertumbuhan dan perkembangannya diatur oleh hormon-hormon reproduksi. Perkembangan ambing terjadi pada masa pubertas, kebuntingan, dan setelah melahirkan. Reseptor beberapa hormon reproduksi, yaitu reseptor estrogen, progesteron, glukokortikoid, prolaktin, laktogen plasenta, insulin, dan oksitosin ada di jaringan mammae (Lérias et al., Available at https://e-journal.unair.ac.id/OVZ/index

2014). Growth hormone (GH) berperan penting tidak hanya pada pertumbuhan tubuh hewan secara umum, namun juga dalam perkembangan ambing dan produksi susu (Bao et al., 2016). Konsentrasi GH yang lebih tinggi terkait dengan produksi susu yang lebih tinggi, sedangkan konsentrasi insulin berkorelasi negatif dengan produksi susu (Lunesu et al., 2021).

Tabel 3 Total konsumsi nutrien pakan dari bahan pakan kambing Peranakan Ettawa

\begin{tabular}{lcc}
\hline \multirow{2}{*}{$\begin{array}{l}\text { komposisi } \\
\text { pakan }\end{array}$} & \multicolumn{2}{c}{$\begin{array}{c}\text { total konsumsi pakan per } \\
\text { ekor }(\mathrm{kg})\end{array}$} \\
\cline { 2 - 3 } & $\mathrm{P} 1$ & $\mathrm{P} 2$ \\
\hline bahan kering & 2,63 & 3,26 \\
Abu & 0,14 & 0,32 \\
protein kasar & 0,56 & 0,58 \\
lemak kasar & 0,25 & 0,24 \\
serat kasar & 0,83 & 0,83 \\
BETN & 0,85 & 1,29 \\
TDN & 2,13 & 2,51 \\
\hline
\end{tabular}

BETN: Bahan Ekstrak Tanpa Nitrogen; TDN:

Total Digestible Nutrient; P1: ransum peternakan 1; P2: ransum peternakan 2. 
Tabel 4 Produksi dan BJ susu kambing

Peranakan Ettawa berdasarkan komposisi pakan

\begin{tabular}{cccc}
\hline & $\begin{array}{c}\text { volume produksi } \\
(\mathrm{mL} / \mathrm{hari})\end{array}$ & $\begin{array}{c}\mathrm{BJ} \\
(\mathrm{kg} / \mathrm{L})\end{array}$ & $\begin{array}{c}\text { berat produksi } \\
(\mathrm{kg} / \mathrm{hari})\end{array}$ \\
\hline P1 & $892,22 \pm 99,92^{\mathrm{a}}$ & $1,02 \pm 0,0$ & $0,91 \pm 0,09$ \\
P2 & $661,11 \pm 19,39^{\mathrm{b}}$ & $1,03 \pm 0,0$ & $0,68 \pm 0,01$ \\
\hline
\end{tabular}

$\mathrm{BJ}$ : berat jenis; P1: ransum peternakan 1; $\mathrm{P} 2$ : ransum peternakan 2 .

Pada kambing betina yang bertumbuh dan mencapai masa pubertas, hipotalamus mulai mengeluarkan gonadotropin releasing hormone (GnRH) yang merangsang pengeluaran FSH dari hipofisa anterior. FSH berperan merangsang pertumbuhan folikel yang selanjutnya folikel menghasilkan estrogen pada fase estrus. Kadar estrogen yang mencapai batas ambang tertentu merangsang dikeluarkannya LH dari hipofisa anterior untuk memicu ovulasi. Sel-sel granulosa pada jaringan sisa ovulasi mengalami luteinasi oleh LH menjadi korpus luteum sebagai penghasil hormon progesteron. Hormon estrogen dan progesteron berperan merangsang perkembangan ambing selama pubertas dan kebuntingan. Ploriferasi sel-sel ambing terjadi selama kebuntingan dan awal laktasi. Hormon estradiol-17 $\beta$, progesteron, prolaktin, hormon pertumbuhan, dan laktogen plasenta bersinergi untuk merangsang pertumbuhan ambing (Zhang et al., 2019). Estrogen merangsang pertumbuhan saluran ambing, sedangkan kombinasi estrogen dan progesteron berperan pada perkembangan lobuli-alveoler. Selama masa kebuntingan, plasenta menghasilkan estrogen dan laktogen berperan pada perkembangan ambing lebih lanjut. Sekresi ambing dihasilkan hanya setelah terbentuknya sistem lobuli-alveoler. Hormon prolaktin, $\mathrm{GH}$, dan glukokortikoid menginduksi produksi susu, sedangkan dan progesteron menghambat produksi susu (Macias dan Hinck, 2012). Pada saat pemerahan jaringan otot polos myo-epitelium berkontraksi, sebagai respon adanya hormon oksitosin, sehingga susu keluar dari lumen alveolus ke saluran susu (Dahl, 2020).

Tabel 5 Kualitas susu kambing Peranakan Ettawa berdasarkan komposisi pakan

\begin{tabular}{cccccc}
\hline & protein $(\%)$ & laktosa $(\%)$ & lemak $(\%)$ & BK (\%) & BKTL (\%) \\
\hline P1 & $5,33 \pm 0,43$ & $3,47 \pm 0,13$ & $5,68 \pm 0,21^{\text {a }}$ & $14,40 \pm 0,36^{\text {a }}$ & $8,71 \pm 0,37$ \\
P2 & $4,89 \pm 0,08$ & $3,51 \pm 0,08$ & $3,42 \pm 0,24^{\text {b }}$ & $12,14 \pm 0,25^{\text {b }}$ & $8,72 \pm 0,29$ \\
\hline
\end{tabular}

Superskrip yang berbeda dalam satu kolom menunjukkan perbedaan nyata ( $\mathrm{p}<0,05)$; P1: ransum peternakan 1; P2: ransum peternakan 2; BJ: berat jenis; BK: bahan kering; BKTL: bahan kering tanpa lemak.

\section{Pengaruh komposisi ransum terhadap produksi susu}

Hasil penelitin ini menujukkan bahwa produksi susu kambing Peranakan Ettawa berikisar antara $0.68 \pm 0.01$ sampai dengan $0.91 \pm 0.09 \mathrm{~kg} /$ hari (Tabel 4). Hasil tersebut lebih tinggi dibandingkan rata-rata produksi susu harian kambing perah Badui (Arab Saudia) yaitu sebesar 0,56 kg (Kouri et al., 2019), namun lebih rendah dibandingkan kambing Baladi (Arab Saudia), yaitu $1.11-1.63 \mathrm{~kg} / \mathrm{hari}$ (El-Tarabany et al., 2018). Perbedaan komposisi tersebut diduga karena perbedaan breed, musim dan pakan. Asupan nutrisi kambing laktasi berpengaruh positif terhadap produksi susu harian (Lunesu et al., 2021).

Kelompok kambing penelitian yang diberi ransum P1 menghasilkan produksi susu yang lebih tinggi daripada kambing yang diberi ransum P2 (Tabel 4). Hal ini karena tingginya bahan kering yang dikonsumsi oleh kambing sehingga meningkatkan konsumsi protein kasar sebagai bahan pakan utama untuk mensintesis susu (Amrudin, 2014). Rendahnya produksi susu pada kambing dengan total konsumsi nutrien pakan P2 sebagai akibat dari rendahnya serat kasar yang dikonsumsi sehingga VFA (Volatile Fatty Acid) yang terbentuk terutama asam propionat di dalam rumen rendah. Asam propionat akan diubah menjadi glukosa sebagai sumber energi untuk memproduksi susu (Herawati, 2003). Kambing dengan total konsumsi nutrien pakan P1 memiliki berat jenis yang lebih rendah dibandingkan kambing dengan total konsumsi nutrien P2 (Tabel 4). Berat jenis yang lebih 
rendah dipengaruhi oleh tingginya kandungan lemak susu pada kambing P1. Lemak memiliki berat jenis yang lebih rendah yaitu $0,916-0,923$ $\mathrm{g} / \mathrm{ml}$ (Mamuaja, 2017).

Karakteristik biokimiawi darah pada saat masa laktasi pada kambing perah dikendalikan oleh hormon tiroid dan kortisol. Kondisi stress menyebabkan terjadi peningkatan kortisol, sehingga menyebabkan terjadi perubahan yang drastis pada fungsi biologis termasuk penurunan nafsu makan, gangguan keseimbangan protein, energi dan mineral esensial dan perubahan reaksi enzimatik, sekresi hormonal serta metabolism tubuh (Sejian et al., 2021). Peningkatan produksi susu, secara signifikan dipengaruhi oleh endokrin, yang meningkatkan mobilisasi jaringan untuk mengkompensasi kekurangan asupan nutrisi untuk produksi susu. Hormon lain yang berperan pada saat laktasi adalah GH yang berperan memelihara pasokan nutrisi ke ambing, melalui perannya untuk merangsang gluconeogenesis, lipolisis dan aliran darah (Zamuner et al., 2020). Partus dan 12 minggu pertama masa laktasi kambing merupakan tahap kritis, dikarenakan terjadi perubahan metabolik yang besar di dalam tubuh. Hormom prolaktin sebagai hormon laktogenik berperan penting dalam mengontrol produksi susu. Prolaktin di dalam plasma akan meningkat sesuai dengan peningkatan proses laktasi, yang puncaknya pada minggu ke-3 dan ke-9 masa laktasi (Henna et al., 2021).

Fotoperiode secara fisiologis akan meningkatkan produksi susu dan memperpanjang masa produksi susu yang sekaligus menghambat aktivitas ovulasi pada kambing perah laktasi. Kondisi fotoperiode yang panjang menyebabkan terjadinya peningkatan prolactin dan penurunan konsentrasi progesteron (Logan et al., 2020). Pengurangan asupan energi (jerami kering) menurunkan meningkatkan kadar insulin dan hormon pertumbuhan, dan penurunan konsentrasi prolactin, yang menyebabkan penurunan produksi susu (Zarrin et al.,2020). Konsumsi protein pakan berkorelasi positif dengan produksi susu (Syafri et al., 2014). Keterbatasan asupan pakan pada musim kering menyebabkan peningkatan kadar IGF-1 (Mabjeesh et al., 2013) dan prolaktin darah namun menurunkan ekspresi reseptor prolaktin (Hooper et al., 2020), diikuti dengan penurunan produksi susu (Mabjeesh et al., 2013).

\section{Pengaruh komposisi ransum terhadap komposisi susu}

Susu kambing pada umumnya mengandung total protein sebesar $30-35 \mathrm{~g} / \mathrm{L}$, terdiri dari $80 \%$ kasein dan $20 \%$ whey, $4,1 \mathrm{~g} / 100 \mathrm{~mL}$ lactose, 3,5 $\mathrm{g} / 100 \mathrm{~mL}$ lemak dan 3,3 g/100 mL total protein (Prosser, 2021). Hasil penelitian ini menujukkan persentase komposisi susu kambing terdiri atas protein 4,89 $\pm 0,08-5,33 \pm 0,43$;

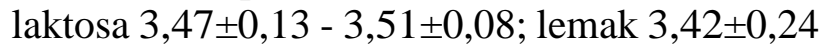
- 5,68 $\pm 0,21$; BK 12,14 $\pm 0,25$ - 14,40 \pm 0.36 ; BKTL 8,71 $\pm 0,37$ - 8,72 $\pm 0,29$. Hasil penelitian ini berbeda dengan persentase komposisi susu beberapa penelitian sebelumnya. Komposisi susu kambing perah Baladi (Arab Saudi), yaitu protein 3,60-3,65\%, lemak 3,27-3,30\%, laktosa $3,85-4,09 \%$, BK 10,99-11,29\%, BKTL 7,747,80\% (El-Tarabany et al., 2018). Komposisi susu kambing perah Badui (Arab Saudi), kandungan lemak susu, protein, laktosa, BKTL dan BK berturut-turut adalah 34,9; 38,9; 48,8; 10,7 dan 6,7 g per L (Kouri et al., 2019). Perbedaan komposisi tersebut diduga karena perbedaan breed, musim dan pakan. Diet berpengaruh menurunkan konsentrasi lemak susu, namun tidak mempengaruhi konsentrasi protein susu (Lunesu et al., 2021).

Kelompok kambing yang mendapatkan asupan total konsumsi nutrien pakan P1 memiliki kandungan lemak susu yang lebih tinggi (Tabel 5). Lemak susu merupakan komponen susu yang paling bervariasi dan mudah berubah bergantung dengan serat kasar yang dikonsumsi. Betahidrosibutirat dari metabolisme ransum digunakan untuk sintesa asam-asam lemak dan untuk pembentukan Acetyl CoA dalam sintesa asam lemak (Dahl, 2020). Serat kasar yang dikonsumsi akan menghasilkan VFA terutama asam asetat yang merupakan bahan pakan utama pembentuk lemak susu (Adriani et al., 2014). Susu kambing dengan total konsumsi nutrien pakan P2 memiliki kandungan BETN (Bahan Ekstrak Tanpa Nitrogen) yang tinggi dapat meningkatkan VFA di dalam rumen khususnya asam propionat sehingga menurunkan kadar asam asetat dalam rumen yang merupakan bahan sintesis lemak susu, sehingga kadar lemak susu kambing P2 
rendah.

Kandungan protein susu pada kambing yang terpapar stres panas mengalami penurunan, tanpa perubahan kandungan lemak susu. Pada kondisi suhu normal, asupan nitrogen dipergunakan untuk fungsi metabolisme bukan untuk sintesis protein susu (Hamzaoui et al., 2013). Kadar protein susu pada kambing dengan total konsumsi nutrien P1 lebih tinggi. Hal ini karena total serat kasar dan protein kasar yang dikonsumsi dalam pakan lebih tinggi. Protein susu (kasein, beta laktoglobulin, dan alphalaktalbumin) merupakan 90\% sampai 95\% dari protein susu yang disintesa didalam kelenjar susu. Plasma protein merupakan sumber bahan pembentuk susu sebanyak $10 \%$ dari yang diperlukan (Dahl, 2020). Protein kasar dalam pakan diubah menjadi glukosa sebagai sumber bahan sintesis protein susu (Rosartio et al., 2015). Protein dalam susu dapat dipengaruhi oleh tingkat energi yang dapat diserap dalam pakan yaitu dalam bentuk TDN (Total Digestible Nutrients) (Astuti et al., 2017).

Konsumsi protein pakan mempunyai hub ungan linier secara timbal balik dengan laktosa susu (Syafri et al., 2014). Kadar laktosa susu pada kambing dengan total konsumsi nutrien pakan P2 sedikit lebih tinggi. Hal ini disebabkan BETN yang dikonsumsi lebih banyak. Konsumsi BETN yang tinggi meningkatkan substrat yaitu glukosa yang dibutuhkan untuk mensintesis laktosa susu (Wulandari, 2017). Laktosa disintesis dari glukosa dan galaktosa. Glukosa adalah substrat terpenting yang digunakan untuk sintesis laktosa. Konsentrasi glukosa darah yang lebih rendah pada kambing terkait dengan pemanfaatan glukosa yang tinggi oleh ambing (Lunesu et al., 2021). Kadar laktosa dan susu harus dipertahankan agar susu isotonis dengan darah, sehingga apabila terjadi kekurangan laktosa menyebabkan kekurangan kandungan air dalam susu. Oleh karena glukosa sebagai bahan utama sintesis laktosa merupakan faktor pembatas produksi susu (Dahl, 2020).

Pada kambing dengan total konsumsi nutrien pakan $\mathrm{P} 1$, kandungan bahan kering susu lebih tinggi, namun bahan kering tanpa lemak sedikit lebih rendah (Tabel 5). Nilai bahan kering sebagian besar dipengaruhi oleh kandungan lemak susu (Saputra, 2018).
Kandungan bahan kering dalam pakan juga mempengaruhi kandungan bahan kering dalam susu (Astuti et al., 2017). Tingginya kandungan lemak dalam susu dapat juga dipengaruhi oleh kandungan protein di dalam susu. Susu dengan kandungan lemak yang tinggi memiliki kandungan bahan kering tanpa lemak yang rendah (Wibowo et al., 2013).

\section{KESIMPULAN}

Kuantitas produksi, kadar lemak dan kadar bahan kering susu yang berasal dari kambing Peranakan Ettawa yang mendapatkan ransum pakan P1 lebih tinggi dibandingkan pada kambing Peranakan Ettawa yang mendapatkan ransum pakan $\mathrm{P} 2$.

\section{DAFTAR PUSTAKA}

Adriani A, Latif A, Fachri S, Sulaksana I. 2014. Peningkatan Produksi dan Kualitas Susu Kambing Peranakan Etawa sebagai Respon Perbaikan Kualitas Pakan. J Ilmiah Ilmu-Ilmu Peternakan 17: 15-21.

Amrudin R, Sambodho P, Suprayogi TH. 2014. Pengaruh Frekuensi Pemberian Hijauan yang Berbeda terhadap Produksi dan Bahan Kering Susu Kambing Perah. J Anim Agric. 3: 242-8.

Astuti P, Suripta H, Sukarini NE. 2017. Produksi dan Komposisi Susu Kambing Peranakan Ettawa melalui Pemberian Ekstrak Meniran. J Ilmu- Ilmu Pertanian. 1: 82-7.

Bao Z, Lin J, Ye L, Zhang Q, Chen J, Yang Q, $\mathrm{Yu}$ Q. 2016. Modulation of Mammary Gland Development and Milk Production by Growth Hormone Expression in GH Transgenic Goats. Front Physiol. 7:278.

Dahl GE. 2020. Chapter 7 - Physiology of lactation in dairy cattle-challenges to sustainable production. Dalam: Bazer FW, Lamb GC, Wu G (Ed). Animal Agriculture. Academic Press. 121-129.

El-Tarabany MS, El-Tarabany AA, Roushdy EM. 2018. Impact of lactation stage on milk composition and blood biochemical and hematological parameters of dairy Baladi goats. Saudi J Biol Sci. 25: 1632-38. 
Hamzaoui S, Salama AA, Albanell E, Such X, Caja G. 2013. Physiological responses and lactational performances of late-lactation dairy goats under heat stress conditions. J Dairy Sci. 96: 6355-65.

Henna K, Boudjellaba S, Khammar F, Amirat Z, Chesneau D, Charallah S. 2021. Endocrine, energy, and lipid status during parturition and early lactation in indigenous goats native to the Algerian Sahara. Vet World 14: 2419-26.

Herawati. 2003. Pengaruh Subtitusi Porsi Hijauan Pakan dalam Ransum dengan Nanas Afkir terhadap Produksi dan Kualitas Susu pada Sapi Perah Laktasi.J Indones Trop Anim Agric. 28: 56-63.

Hooper HB, Silva PDS, de Oliveira SA, Meringhe GKF, Lacasse P, Negrão JA. 2020. Effect of heat stress in late gestation on subsequent lactation performance and mammary cell gene expression of Saanen goats. J Dairy Sci. 103: 1982-92.

Kouri F, Charallah S, Kouri A, Amirat Z, Khammar F. 2019. Milk production and its relationship with milk composition, body and udder morphological traits in Bedouin goat reared under arid conditions. Acta Sci Anim Sci. 41: e42552.

Lérias JR, Hernández-Castellano LE, SuárezTrujillo A, Castro N, Pourlis A, Almeida AM. 2014. The mammary gland in small ruminants: major morphological and functional events underlying milk production--a review. J Dairy Res. 81: 30418.

Logan KJ, Leury BJ, Russo VM, Cameron AWNS, Tilbrook AJ, Dunshea FR. 2020. An Extended Photoperiod Increases Milk Yield and Decreases Ovulatory Activity in Dairy Goats. Animals (Basel) 10: 1879.

Lunesu MF, Decandia M, Molle G, Atzori AS, Bomboi GC, Cannas A. 2021. Dietary Starch Concentration Affects Dairy Sheep and Goat Performances Differently during Mid-Lactation. Animals (Basel) 11: 1222.

Luo J, Wang W, Sun S. 2019. Research advances in reproduction for dairy goats. AsianAustralas J Anim Sci. 32: 1284-95.

Mabjeesh SJ, Sabastian C, Gal-Garber O, Shamay A. 2013. Effect of photoperiod and heat stress in the third trimester of gestation on milk production and circulating hormones in dairy goats. J Dairy Sci. 96: 189-97.

Macias H, Hinck L. 2012. Mammary gland development. Wiley Interdiscip Rev Dev Biol. 1: 533-57.

Mamuaja CF. 2017. Lipida. Unsrat Press. Manado.

Mauladi MAR, Harisudin M, Sundari MT. 2018. Strategi Pengembangan Peternakan Kambing Perah Adilla Goat Farm di Kabupaten Karanganyar dengan metode AHP. AGRISTA 6: 12-22

Pribadiningtyas PA, Suprayogi TH, Sambodo P. 2012. Hubungan antara bobot badan, volume ambing terhadap produksi susu kambing perah laktasi Peranakan Ettawa. Anim Agric J. 1: 99 -105.

Profil Kota Batu. 2021. https://ciptakarya. pu.go.id/profil/profil/barat/jatim/batu.pdf diakses:1 Juli 2021.

Prosser CG. 2021. Compositional and functional characteristics of goat milk and relevance as a base for infant formula. J Food Sci. 86: 257-65.

Rosartio R, Suranindyah Y, Bintara S, Ismaya I. 2015. Produksi dan Komposisi Susu Kambing Peranakan Ettawa di Dataran Tinggi dan Dataran Rendah Daerah Istimewa Yogyakarta. Buletin Peternakan 39: $180-8$.

Saputra FT. 2018. Evaluasi Total Solid Susu Segar Peternakan Tawang Argo Berdasarkan Standard Nasional Indonesia. J Ternak Tropika 19: 22-6.

Sejian V, Silpa MV, Reshma Nair MR, Devaraj C, Krishnan G, Bagath M, Chauhan SS, Suganthi RU, Fonseca VFC, König S, Gaughan JB, Dunshea FR, Bhatta R. 2021. Heat Stress and Goat Welfare: Adaptation and Production Considerations. Animals (Basel) 11: 1021.

Svennersten-Sjaunja K, Olsson K. 2005. Endocrinology of milk production. Domest Anim Endocrinol. 29: 241-58.

Syafri A, Harjanti DW, Santoso SAB. 2014. Hubungan antara konsumsi protein pakan dengan produksi kandungan protein dan laktosa susu sapi perah di kota Salatiga. Anim Agric J. 3: 450-6. 
Wasiati H, Edi F. 2018. Peternakan Kambing Peranakan Etawa di Kabupaten Bantul. J Abdimas Unmer Malang 3: 8-14.

Wibowo PA, Astuti TY, Soediarto P. 2013. Kajian Total Solid (TS) dan Solid Non Fat (SNF) Susu Kambing Peranakan Ettawa (PE) pada Satu Periode Laktasi. J Imiah Peternakan 1: 214-21.

Wulandari S, Hariadi M, Widodo OS. 2017. Pengaruh Pemberian Konsentrat pada Periode Laktasi terhadap Berat Jenis, Kadar Lemak dan Kadar Bahan Kering Susu Sapi. J Agroveteriner 5: 180-8.

Zamuner F, DiGiacomo K, Cameron AWN, Leury BJ. 2020. Endocrine and metabolic status of commercial dairy goats during the transition period. J Dairy Sci. 103: 5616-28.
Zarrin M, Sanginabadi M, Nouri M, Ahmadpour A, Hernández-Castellano LE. 2021 Prepartum and Postpartum Feed Restrictions Affect Blood Metabolites and Hormones Reducing Colostrum and Milk Yields in Fat-Tailed Dairy Sheep. Animals (Basel) 11: 1258.

Zhang W, Chen J, Zhao Y, Zheng Z, Song Y, Wang H, Tong D. 2019. The inhibitory effect of melatonin on mammary function of lactating dairy goats. Biol Reprod. 100: 45567. 